\title{
Effect of plant growth promoting Rhizobacteria (PGPRS) on yield and quality of processing tomato under water deficiency
}

\author{
Bulgan Andryei - Kitti Zsuzsanna Horváth - Szilvia Ráth - Eszter Nemeskéri - András Neményi - \\ Zoltán Pék - Lajos Helyes
}

Institute of Horticulture, Faculty of Agricultural and Environmental Sciences, Szent István University, Gödöllő, H-2100 Gödöllő, Hungary bulgan.mgl@muls.edu.mn

\section{SUMMARY}

Chlorophyll fluorescence was measured of H1015 tomato hybrid with different bacterial treatments (B0-B1-B2-B3) and three irrigation treatments: regular irrigated (RI), deficit irrigated (DI) and non-irrigated conditions (IO). The aim of the experiments was to show the effects of plant growth promoting rhizobacteria on the yield, dry matter and vitamin $C$ content of processing tomato during different irrigation treatments, and measuring the chlorophyll fluorescence during the ripening and development stages. According to the results, none of the bacterial treatments had a statistical effect on the quantity and quality of the tomato and on the chlorophyll fluorescence, only the irrigation. Further studies are needed.

Keywords: Vitamin C, Brix, chlorophyll fluorescence

\section{INTRODUCTION}

Tomato (Lycopersicon esculentum Mill.) is one of the most widely grown horticultural crops in the world, one quarter of which is grown for industrial use (Helyes et al., 2010; Paoloa et al., 2018). Consuming tomatoes, even in processed form, reduces the risk of developing certain types of cancer (Nguyen and Schwartz, 1999). Tomato's vitamin $\mathrm{C}$ content, carotenoid components, especially lycopene and $\beta$-carotene, have a positive effect on human health (Aust et al., 2003; Markovic' et al., 2006; Favati et al., 2009).

Plant growth promoting rhizobacteria (PGPR) are soil bacteria with some beneficial effects on soil properties, plant growth and the environment. They live in symbiosis with plant roots and can increase plant productivity and immunity (Yang et al., 2009; Miransari, 2014).

The nutrient content of tomatoes is most influenced by genetic and environmental factors, as well as the ripening stage, but agricultural practices such as irrigation can also change their nutrient parameters (Dumas et al., 2003; Javanmardi and Kubota, 2008; Paoloa et al., 2018). Tomatoes have remarkable concentrations of folate, vitamin $\mathrm{C}$, and vitamin $\mathrm{E}$ (Gahler et al., 2003). Total vitamin $\mathrm{C}$ levels range from about 8 to $40 \mathrm{mg} 100 \mathrm{~g}^{-1}$ between species and varieties (Bertin and Génard, 2018).

The most important quality factor of processing tomato is the dry matter content $\left(\mathrm{Brix}^{\circ}\right)$, which can be very high without irrigation, although there is limited variability in commercial tomato cultivars (4.5-6.25\%) (Poysa, 1993; Patanè and Cosentino, 2010; Le et al., 2018). Several experiments have shown that increasing the water supply significantly increases the yield, reduces the Brix content of the fruit however the Brix yield $\left(\mathrm{t} \mathrm{ha}^{-1}\right)$ is significantly increased (Helyes et al., 2010).

The photosynthetic activity of plants is also an important factor that influences the yield. The most sensitive period of tomatoes grown under water scarcity is from fruit setting to the end of fruit development, when the photosynthetic activity of the varieties can be effectively monitored by measuring chlorophyll fluorescence (Fv/Fm) (Nemeskéri et al., 2019).

Water supply is important for yield quantity and quality. Deficit irrigation has been shown to reduce the production costs, preserve the water consumption, and it also has a positive effect on the processing quality of tomatoes (Favati et al., 2009; Patanè et al., 2011).

The purpose of our experiment is to observe the effects of plant growth promoting rhizobacteria on the yield, dry matter and vitamin $\mathrm{C}$ content of processing tomato during different irrigation treatments, and measuring the chlorophyll fluorescence during the ripening and development stages.

\section{MATERIALS AND METHODS}

In 2018, open field experiments were conducted on the Institute of Horticulture's farm at Szent István University, Gödöllö, Hungary. The tomato cultivar distributed by Heinz was H1015 hybrid with early ripening (114 days).

The experiments were carried out in split-plot design with randomized complete blocks in four repetitions. The plantings were in $120 \mathrm{~cm} \mathrm{x} 40 \mathrm{~cm}$ twin rows, where the length of rows was $25 \mathrm{~m}$ and the space between the tomatoes was $20 \mathrm{~cm}$. The date of transplantation was May $17^{\text {th }}$ and the harvest date was August $27^{\text {th }}$.

On the basis of crop evapotranspiration using the equation $\mathrm{ETc}=\mathrm{ET} 0 \times \mathrm{Kc}$, two different irrigation treatments were performed: regular water supply (RI) and deficit irrigation (DI) where half of irrigated doses of RI treatment was applied. Non-irrigated plots represented the rain-fed control (I0). The irrigation was done with a drip system.

There were 3 bacteria and one bacterial-free treatment: B1, B2, B3 and B0. The bacteria were given by BAY-BIO Institute (Szeged) for the experiments. 
Seedlings were soaked in 20 litre of water containing 2 $\mathrm{dl}$ of bacteria before planting in every treatment.

The chlorophyll fluorescence of leaf was measured with portable PAM-2500 (Waltz, Germany). 10 plants were harvested from each plot per repetition. The total biomass and yield were weighed, then the yield was classified to the marketable (ripe) and non-marketable (green and diseased) fruits and measured for yield. The soluble solid contents ( $\left.{ }^{\circ} \mathrm{Brix}\right)$ and vitamin $\mathrm{C}$ of fruits were analysed.

Data were evaluated by analysis of variance (ANOVA) using SPSS 20.0 for Windows software.
The average values of treatments were compared by Duncan's Multiple Range Test at $\mathrm{P}<0.05$.

\section{RESULTS AND DISCUSSION}

The distribution of precipitation varied during the developmental stages of tomatoes, but 2018 can be considered as a dry year (Figure 1). From the planting, $305 \mathrm{~mm}$ of rain fell until the harvest. During the fruit setting (ST2) and fruit development (ST3) stages, there was low precipitation ( $35 \mathrm{~mm}$ and $18 \mathrm{~mm}$ ), and the maximum temperature was over $30{ }^{\circ} \mathrm{C}$, while the minimum temperature was above $15^{\circ} \mathrm{C}$.

Figure 1: Temperature and rain in $\mathbf{2 0 1 8}$

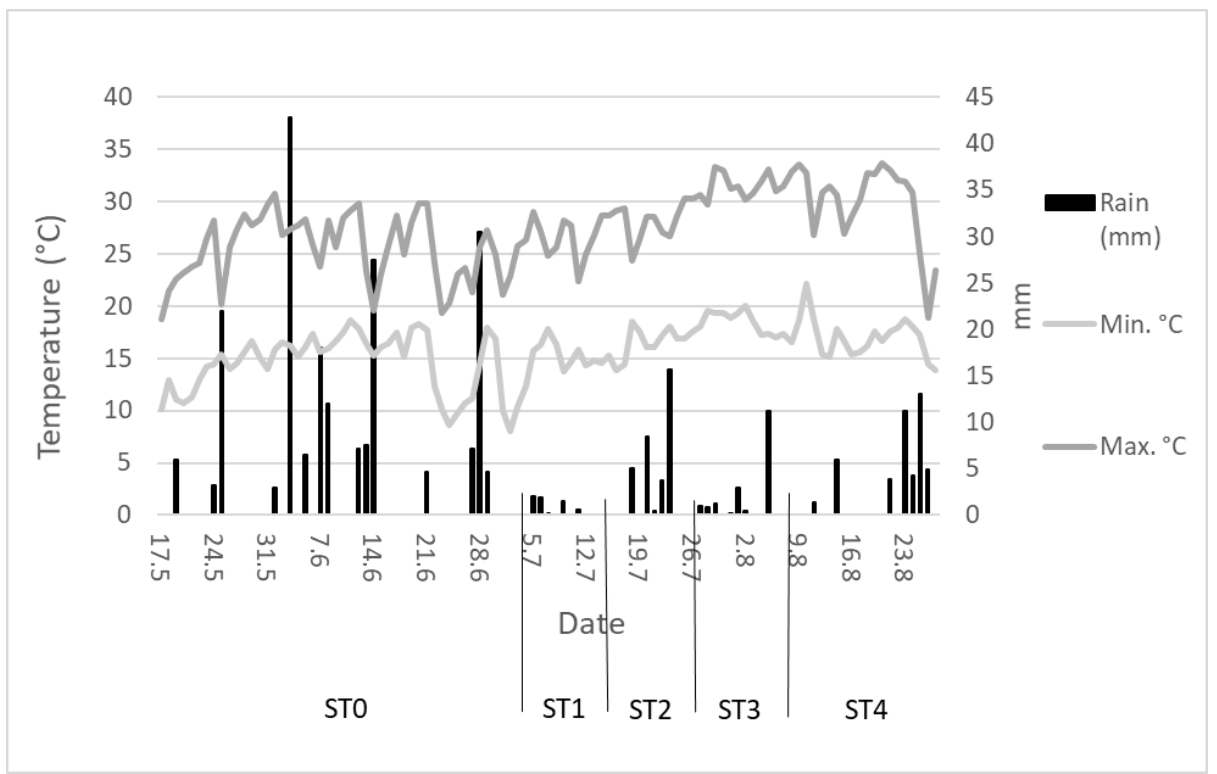

ST1=flowering, ST2=flowering and fruit setting, ST3= fruit development, ST4= fruit ripening

Figure 2 shows the chlorophyll fluorescence results of a tomato in two phenological stages: during the fruit development and the ripening stages. Chlorophyll fluorescence $(\mathrm{Fv} / \mathrm{Fm})$ in $\mathrm{B} 0$ and $\mathrm{B} 1$ treated plants significantly differed from B2 and B3 ones in all water supply conditions. Under nonirrigated conditions, the B2 plants had the lowest Fv/Fm value, while the highest chlorophyll fluorescence was detected in the non-bacterial treated plants. In the case of deficit irrigation (DI), B3 plants showed the lowest $\mathrm{Fv} / \mathrm{Fm}$ value in comparison with the untreated plants (B0). The finding showed that the untreated $(\mathrm{B} 0)$ and the $\mathrm{B} 1$ treated plants had higher chlorophyll fluorescence in all three irrigation stages during fruit development and ripening stages.
Figure 2: Effect of plant growth promoting rhizobacteria strains on chlorophyll fluorescence (Fv/Fm) during fruit development and ripening stages under regular irrigated (RI) deficit irrigated (DI) and non-irrigated conditions (0)

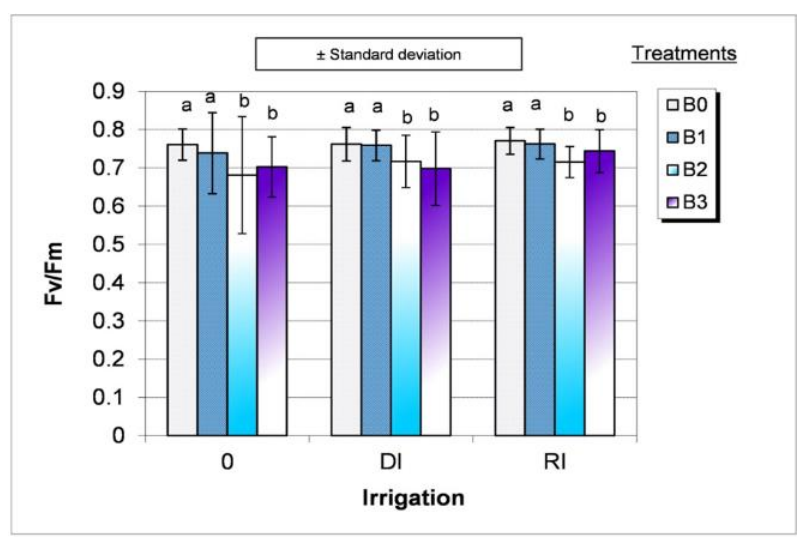


PGPRs increased significantly the weight of marketable and green fruits of tomato however they did not influence the quality of fruits, contrary to expectations. B2 and B3 treatments increased the weight of tomato fruits (Table 1) while B1 indicates minimal bacterial activity for Brix mainly under nonirrigated condition. Deficit irrigation has increased the weight of marketable (red) fruits, but a small increase in the weight of green and diseased fruits can be detected. Under regular irrigation, weight of marketable (red) fruits were statistically the same as marketable fruits produced in deficit irrigation, but the plants produced more than $20 \%$ more weighed green and diseased fruits under regular irrigated condition than deficient irrigated ones. These are proved by the correlation between the water supply conditions and green fruits yield ( $\mathrm{r}=0.5089)$ shown on Table 2 . The results showed that increasing dose of irrigation decreased the dry matter content of tomato fruits but the decrease in vitamin $\mathrm{C}$ content of fruits did not differ significantly between deficit and regularly irrigated conditions (Table 1). Although, a weak correlation between the PGPRs and Fv/Fm measured during fruit development and ripening could be detected, Fv/Fm was not related to the weight and quality of fruits (Table 2).

Effect of water supplies and PGPR treatments on fruit yield and quality of processing tomato

\begin{tabular}{|c|c|c|c|c|c|c|}
\hline Irrigation & PGPRs & $\begin{array}{l}\text { Marketable } \\
\text { fruit weight } \\
\text { (g) }\end{array}$ & $\begin{array}{c}\text { Green fruit } \\
\text { weight } \\
\text { (g) }\end{array}$ & $\begin{array}{l}\text { Diseased fruit } \\
\text { weight (g) }\end{array}$ & Brix $^{\circ}$ & $\begin{array}{c}\text { Vitamin C } \\
\mu \mathrm{g} \mathrm{g}^{-1}\end{array}$ \\
\hline \multirow[t]{4}{*}{$\mathrm{I} 0$} & B0 & $54.23 \mathrm{~b}$ & $22.77 \mathrm{e}$ & $29.69 \mathrm{e}$ & $4.25 \mathrm{~b}$ & $51.79 \mathrm{a}$ \\
\hline & B1 & $46.69 \mathrm{c}$ & $19.23 \mathrm{~d}$ & $32.31 \mathrm{~d}$ & $5.07 \mathrm{a}$ & $56.02 \mathrm{a}$ \\
\hline & B2 & $57.44 \mathrm{a}$ & $29.31 \mathrm{~b}$ & $35.80 \mathrm{c}$ & $4.36 \mathrm{~b}$ & 50.72 a \\
\hline & B3 & $54.37 \mathrm{ab}$ & $24.90 \mathrm{c}$ & $42.56 \mathrm{~b}$ & $4.39 \mathrm{~b}$ & $50.62 \mathrm{a}$ \\
\hline Effect of I0 & & $53.13 \mathrm{~B}$ & $24.05 \mathrm{~B}$ & $35.09 \mathrm{BC}$ & $4.52 \mathrm{~A}$ & $52.29 \mathrm{~A}$ \\
\hline \multirow[t]{4}{*}{ DI } & B0 & $53.34 \mathrm{~b}$ & $23.40 \mathrm{c}$ & $35.85 \mathrm{c}$ & $3.65 \mathrm{c}$ & $43.34 \mathrm{~b}$ \\
\hline & B1 & $55.03 \mathrm{~b}$ & 29.49 b & $36.41 \mathrm{c}$ & $3.51 \mathrm{c}$ & $40.98 \mathrm{~b}$ \\
\hline & B2 & $61.49 \mathrm{a}$ & $30.01 \mathrm{~b}$ & $45.69 \mathrm{~b}$ & $3.61 \mathrm{c}$ & $45.36 \mathrm{~b}$ \\
\hline & B3 & $58.58 \mathrm{a}$ & $29.09 \mathrm{~b}$ & $35.94 \mathrm{c}$ & $3.69 \mathrm{c}$ & $44.93 \mathrm{~b}$ \\
\hline Effect of DI & & $57.11 \mathrm{~A}$ & $28.00 \mathrm{~B}$ & $38.47 \mathrm{AB}$ & $3.62 \mathrm{~B}$ & $43.65 \mathrm{~B}$ \\
\hline \multirow[t]{4}{*}{ RI } & B0 & $57.27 \mathrm{a}$ & $31.36 \mathrm{~b}$ & $53.88 \mathrm{a}$ & $3.37 \mathrm{c}$ & $39.64 \mathrm{~b}$ \\
\hline & B1 & $54.28 \mathrm{ab}$ & $30.95 \mathrm{~b}$ & $48.69 \mathrm{~b}$ & $3.46 \mathrm{c}$ & $43.66 \mathrm{~b}$ \\
\hline & B2 & $55.28 \mathrm{ab}$ & $31.79 \mathrm{~b}$ & $48.19 \mathrm{~b}$ & $3.33 \mathrm{c}$ & $42.51 \mathrm{~b}$ \\
\hline & B3 & $57.47 \mathrm{a}$ & $43.12 \mathrm{a}$ & $43.91 \mathrm{~b}$ & $3.22 \mathrm{c}$ & $42.57 \mathrm{~b}$ \\
\hline Effect of RI & & $56.07 \mathrm{~A}$ & $34.30 \mathrm{~A}$ & $48.67 \mathrm{~A}$ & $3.35 \mathrm{C}$ & $42.09 \mathrm{~B}$ \\
\hline \multirow[t]{4}{*}{ PGPRs } & B0 & $54.88 \mathrm{ab}$ & $25.84 \mathrm{~b}$ & $39.81 \mathrm{a}$ & $3.76 \mathrm{~b}$ & $44.92 \mathrm{a}$ \\
\hline & B1 & $52.00 \mathrm{~b}$ & $26.56 \mathrm{ab}$ & $39.14 \mathrm{a}$ & $4.02 \mathrm{a}$ & $46.88 \mathrm{a}$ \\
\hline & B2 & $58.07 \mathrm{a}$ & $30.37 \mathrm{a}$ & $43.22 \mathrm{a}$ & $3.77 \mathrm{~b}$ & $46.20 \mathrm{a}$ \\
\hline & B3 & $56.80 \mathrm{a}$ & $32.37 \mathrm{a}$ & $40.80 \mathrm{a}$ & $3.77 \mathrm{~b}$ & $46.04 \mathrm{a}$ \\
\hline \multirow[t]{4}{*}{ significance } & irr. & $*$ & $* *$ & $*$ & $* * *$ & $* * *$ \\
\hline & PGPRs & $* *$ & $t$ & ns & $*$ & ns \\
\hline & irr. $\mathrm{x}$ & 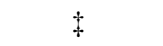 & $\mathrm{ns}$ & ns & $* *$ & $\mathrm{~ns}$ \\
\hline & PGPRs & & & & & \\
\hline
\end{tabular}

$* \mathrm{P}<0.05, * * \mathrm{P}<0.01, * * * \mathrm{P}<0.001 \ddagger \mathrm{P}<0.1$

Capital letter $=$ significant difference of water supplies, smaller letter=significant difference of bacteria treatments

Relationship among water supply, chlorophyll fluorescence (Fv/Fm), PGPRs and yield and quality of tomato fruits

\begin{tabular}{lccccc}
\hline Factors & Fv/Fm & $\begin{array}{c}\text { Marketable } \\
\text { fruits weight }\end{array}$ & $\begin{array}{c}\text { Green fruits } \\
\text { weight }\end{array}$ & $\begin{array}{c}\text { Diseased } \\
\text { fruits } \\
\text { weight }\end{array}$ & $\begin{array}{c}\text { Brix }^{\circ} \\
\boldsymbol{\mu g}^{-1}\end{array}$ \\
\hline Water supply & 0.2047 & -0.3422 & $0.5089 * *$ & $0.3767 *$ & $-0.8363 * * *$ \\
PGPRs & $-0.4329 * *$ & 0.2756 & 0.3412 & 0.0646 & $-0.6880^{* *}$ \\
Fv/Fm & - & -0.0802 & -0.0789 & -0.1659 & -0.1698 \\
\hline
\end{tabular}




\section{CONCLUSIONS}

During fruit development and ripening stages, the untreated (B0) and the B1 treated plants had higher chlorophyll fluorescence values under all three irrigation stages, than the B2 and B3 treated plants.

The results showed that bacterial treatments had no statistical effect on quality and quantity, unlike irrigation. Both deficit and regular irrigations increased the weight of marketable fruits, but also increased the green and diseased fruits weight.

The dry matter and vitamin $\mathrm{C}$ content of the fruits was also reduced by irrigation, but the bacteria had no effect on them.

\section{ACKNOWLEDGEMENTS}

This research was funded by the Ministry of Human Capacities grant Higher Education Institutional Excellence Program in the framework of the water related research of Szent István University, GINOP_2.2.1_15_2016_00003 and grant number EFOP-3.6.3-VEKOP-16-2017-00008 and TUDFO/47138/2019-ITM.

\section{REFERENCES}

Aust, O.-Ale-Agha, N.-Zhang, L.-Wollersen, H.-Sies, H.-Stahl, W (2003): Lycopene oxidation product enhances gap junctional communication. Food Chem. Toxicol. 41. 1399-1407.

Bertin, N.-Génard M. (2018): Tomato quality as influenced by preharvest factors. Scientia. Hortic-Amsterdam 233. 264-276.

Dumas, Y.-Dadomo, M.-Di Lucca, G.-Grolier P. (2003): Effects of environmental factors and agricultural techniques on antioxidant content of tomatoes. J. Sci. Food Agric. 83. 369-382.

Favatim, F.-Lovelli, S.-Galgano, F.-Miccolis, V.-Tommaso, T.D.Candido, V. (2009): Processing tomato quality as affected by irrigation scheduling. Scientia Hortic-Amsterdam 122. 562-571.

Gahler, S.-Otto, K.-Böhm, V. (2003): Alterations of Vitamin C, Total Phenolics, and Antioxidant Capacity as Affected by Processing Tomatoes to Different Products. J. Agric. Food Chem. 51. 7962-7968.

Helyes, L.-Bőcs, A.-Pék, Z. (2010): Effect of water supply on canopy temperature, stomatal conductance and yield quantity of processing tomato (Lycopersicon esculentum Mill.). International Journal of Horticultural Science (in Hungary) 16. 5: $13-15$.

Javanmardi, J.-Kubota, C. (2008): Variation of lycopene, antioxidant activity, total soluble solids and weight loss of tomato during postharvest storage. Postharvest Biol. Technol. 41. 151-155.

Le, A.T.-Pék, Z.-Takács, S.-Neményi, A.-Helyes, L. (2018) The effect of plant growth-promoting rhizobacteria on yield, water use efficiency and Brix Degree of processing tomato. Plant, Soil Environ 64. 11: 523-529.
Markovic, K.-Hruskar, M.-Vahc 'ie', N. (2006): Lycopene content of tomato products and their contribution to the lycopene intake of Croatians. Nutr. Res. 26. 556-560.

Miransari, M. (2014): Plant Growth Promoting Rhizobacteria. J. Plant Nutr 37: 1-9.

Nemeskéri, E.-Horváth, K.-Pek, Z.-Helyes, L. (2019): Effect of mycorrhizal and bacterial products on the traits related to photosynthesis and fruit quality of tomato under water deficiency conditions. Acta Hortic. 1233: 61-66.

Nguyen, M.L.-Schwartz, S.J. (1999): Lycopene: chemical and biological properties. Food Technol. 53. 38-45.

Paoloa, D.-Bianchia, G.-Scalzoa, R.L.-Morellib, C.F.-Rabuffettic, M.-Speranza, G. (2018): The Chemistry behind Tomato Quality. Natural Product Communications 13. 9: 1225 - 1232.

Patanè, C.-Cosentino, S.L. (2010): Effects of soil water deficit on yield and quality of processing tomato under a Mediterranean climate. Agrl Water Manage, 97: 131-138.

Patanè, C.-Tringali, S.-Sortino, O. (2011): Effects of deficit irrigation on biomass, yield, water productivity and fruit quality of processing tomato under semi-arid Mediterranean climate conditions. Scientia Hortic-Amsterdam 129. 590-596.

Poysa, V. (1993): Use of Lycopersicon cheesmanii and $L$. chmielewskii to increase dry matter content of tomato fruit. Can. J. Plant Sci. 73: 273-279.

Yang, J.-Kloepper, J.W.-Ryu, C.M. (2009): Rhizosphere bacteria help plants tolerate abiotic stress. Plant Science 14. 1: 1-4. 